\title{
MEMBANGUN PASAR EKONOMI DIGITAL PERSPEKTIF SYARIAH
}

\author{
Niken Lestari \\ Institut Agama Islam Nahdlatul Ulama Kebumen
}

sayanikenlestari@gmail.com

\begin{abstract}
ABSTRAK
Tujuan adanya bisnis adalah menyenangkan atau memuaskan konsumen dengan menawarkan barang, jasa bahkan ide ataupun pemikiran yang bernilai nyata. Pelanggaran aktivitas bisnis yang dilakukan pelaku bisnis adalah sikap tidak jujur terhadap konsumen terhadap produk yang ditawarkan seperti tidak jujur terhadap produknya sendiri atau menyembunyikan informasi produk tersebut.

Jenis penelitian ini adalah penelitian kepustakaan (library research). Metode yang digunakan untuk menganalisisnya adalah content analysis (analisis isi), karena penelitian ini adalah document analysis (analisis dokumen). Pendekatan yang digunakan adalah maqasid syariah.

Indonesia yang mayoritas penduduknya beragama Islam, namun ternyata masih banyak penyimpangan-penyimpangan terjadi yang tidak sesuai dengan prinsip syariah. Hal ini mungkin terjadi karena ketidak tahuan masyarakat kita terhadap menjalankan bisnis yang sesuai prinsip syariah dan tentu saja menimbulkan ketidaktahuan ini kerugian bagi orang lain. Terdapat beberapa aspek yang bisa dijadikan solusi untuk menghindari penyimpanganpenyimpangan yang terjadi mulai dari peran pelaku bisnis online sampai peran pemerintah yang cukup mendukung. Apabila semuanya ini telah dilakukan, pasar ekonomi digital perspektif syariah akan tercapai. Sudah saatnya bagi negara Indonesia membangun pasar, bukan seperti selama ini yang menjadi target pasar.
\end{abstract}

Kata Kunci: Bisnis Online, E-Commerce, Ekonomi Digital

\section{PENDAHULUAN}

Dalam dua dekade ini, terhitung sejak fase awal perkembangan internet di Indonesia tahun 1990an, jumlah pengguna internet meningkat dengan amat pesat. Hal ini terjadi beriringan pula dengan ekspansi kelas menengah, pertumbuhan 
ekonomi negara, dan proses demokratisasi. Salah satu trend yang berkembang dalam industri telekomunikasi adalah smartphone, bertambahnya pengguna jejaring sosial, serta pertumbuhan insfrastruktur internet. Asosiasi Penyelenggara Jasa Internet di Indonesia telah melakukan survey pada tahun 2017 terkait dengan perkembangan internet di Indonesia. Berikut grafik surve APJII yang menggambarkan jumlah dan penetrasi pengguna internet di Indonesia sampai dengan tahun 2017. Teknologi informasi menjadi salah satu isu dalam Masyarakat Ekonomi ASEAN yang akan dibuka mulai akhir Desember 2015. Namun, dalam cetak biru lanjutannya, yakni Masyarakat Ekonomi ASEAN 2025, isu ini semakin diperdalam. Sebab, banyak dinamika yang terjadi di dunia teknologi informasi selama lima tahun terakhir. Dilihat dari kesiapannya masyarakat Indonesia saat ini untuk menghadapi MEA memang belum siap, terlebih para usaha mikro UKM yang sulit untuk menghadapinya. Peran teknologi internet bagi para usaha mikro memang cukup membantu untuk perluasan pasar baik melalui website toko online maupun berbagai jejaring sosial.

Namun seiring dengan perkembangan teknologi dalam melakukan transaksi yang semakin berkembang ini, ternyata turut pula menimbulkan berbagai permasalahan. Beberapa permasalahan yang dapat muncul dalam transaksi on-line misalnya:

1. kualitas barang yang dijual, hal ini dikarenakan pembeli tidak melihat secara langsung barang yang akan dibeli. Penjual hanya melihat tampilan gambar dari barang yang akan dijual;

2. potensi penipuan yang sangat tinggi, dimana ketika pembeli sudah melakukan pembayaran namun barang tidak kunjung diantar kepada pembeli;

3. potensi gagal bayar dari pembeli, dimana ketika penjual sudah mengirimkan barang kepada pembeli namun pembayaran tidak kunjung dilakukan oleh pembeli. 
Permasalahan timbul dari adanya aktivitas bisnis adalah mengenai tanggungjawab terhadap konsumen atau pelanggan. Dimana tujuan adanya bisnis adalah menyenangkan atau memuaskan konsumen dengan menawarkan barang, jasa bahkan ide ataupun pemikiran yang bernilai nyata. Pelanggaran aktivitas bisnis yang dilakukan pelaku bisnis adalah sikap tidak jujur terhadap konsumen terhadap produk yang ditawarkan seperti tidak jujur terhadap produknya sendiri atau menyembunyikan informasi produk tersebut.

Dengan melihat pada berbagai permasalahan di atas, maka penelitian ini bertujuan untuk mengkaji bagaimanakah perspektif syariah dalam melihat perkembangan transaksi jual beli dengan menggunakan media on-line yang tujuannya untuk membangun pasar ekonomi digital di Indonesia, serta apa saja yang harus dilakukan untuk meminimalisasi berbagai permasalahan di atas.

\section{METODE DAN PENDEKATAN}

Jenis penelitian ini adalah penelitian kepustakaan (library research). Metode yang digunakan untuk menganalisisnya adalah content analysis (analisis isi), karena penelitian ini adalah document analysis (analisis dokumen). Pendekatan yang digunakan adalah maqasid syariah.

\section{PEMBAHASAN}

\section{Pasar Ekonomi Digital}

Ekonomi digital merupakan salah satu tren peluang bisnis ke depan. Oleh karena itu, mulai sekarang pemerintah harus mempersiapkan instrumen yang diperlukan agar tidak ketinggalan dalam memanfaatkan kesempatan tersebut. Ekonomi digital adalah suatu hal yang kompleks dan merupakan fenomena yang baru muncul terkait dengan aspek-aspek ekonomi mikro, ekonomi makro, dan teori organisasi dan administrasi. Ekonomi digital akan menjelaskan perkembangan dan pertumbuhan ekonomi beberapa dekade yang akan datang. 
E-Commerce sekarang memang berkembang cukup bagus di negara Indonesia, sebagai contoh UKM yang dulunya susah untuk memasuki pasar sekarang bisa masuk pasar dengan mudah bahkan ke pasar luar negeri. Perkembangan ini merambah ke berbagai sektor seperti sektor transportasidan sektor kesehatan. Di sektor transportasi misal dengan munculnya ojek online (Go-jek)dan taksi online (GrabTaxi dan Uber). Hal ini tentunya memungkinkan sektor-sektor lain untuk bergerak secara online.

F-Pada 2020, volume bisnis e-commerce di Indonesia diprediksi mencapai USD 130 miliar dengan angka pertumbuhan per tahun sekitar 50\%. Pemerintah ingin menempatkan Indonesia sebagai Negara Ekonomi Digital terbesar di Asia Tenggara pada 2020. Untuk mencapai target, pemerintah akan meluncurkan e-Commerce Roadmap dan target 1.000 technopreneurs baru pada 2020 dengan valuasi bisnis USD 10 miliar. ${ }^{1}$ Cukup mungkin bagi Indonesia untuk mewujudkan ekonomi digital yang bisa meningkatkan ekonomi masyarakat maupun negara. Dengan adanya ekonomi digital Indonesia dapat membangun pasar sendiri tidak seperti sekarang ini yang masih menjadi pasar sasaran luar negeri. Perilaku browsing dengan lebih sering dilihat dapat lebih meningkatkan pembelian secara online. Selain itu konsumen yang kebanyakan anak muda atau remaja dengan seringnya browsing, misal: streaming video, sosial media, forum, game, atau lelang. Oleh karena itu, untuk menekankan manfaat tersebut, sebuah situs perlu mengidentifikasi basis pengguna yang biasa mengunjungi dan terlibat dalam kategori produk. Produk dan jasa dengan hobi atau antusiasme adalah persaingan sehat untuk situs yang mencampur e-commerce dengan jejaring sosial. Fitur yang ditawarkan di situs perlu memahami produk dan penggunanya, rata-rata waktu yang dihabiskan oleh pengguna dikaitkan dengan tujuan versus orientasi pengalaman, dengan begitu perusahaan dapat memperkirakan presentase pembeli dan pembeli yang berorientasi pada tujuan versus pengalaman. ${ }^{2}$ terbesar-di-asean

http://bisnis.tempo.co/read/news/2015/11/16/280719220/ekonomi-digital-indonesia-akan-

${ }^{2}$ Mary Wolfinbarger and Mary Gilly, "Consumer motivation for Online Shopping”, This research has been supported by grants from the CISE/IIS/CSS Division of the U.S. National Science Foundation 
Berdasarkan analisis, ada enam isu penghambat pertumbuhan e-commerce di Indonesia, yaitu pendanaan, perpajakan, perlindungan konsumen, infrastruktur komunikasi, logistik, lalu edukasi dan sumber daya manusia. Isu-isu ini harus dikerjakan bersama dengan lembaga terkait agar menghasilkan kebijakan yang komprehensif dan sinkron.

\section{PELAKU BISNIS ONLINE}

Dalam wikipedia, online adalah keadaan di saat seseorang terhubung ke dalam suatu jaringan ataupun sistem yang lebih besar. ${ }^{3}$ Jaringan sosial secara pribadi telah mempengaruhi pengalaman belanja secara offline, pengenalan mereka ke dunia online adalah fenomena yang relatif baru. Banyak sekali situssitus toko online dan telah berhasil mengintegrasi review produk, rekomendasi, mencari produk perbandingan. Tetapi, banyak situs lebih lambat dalam mengadopsi fitur jejaring sosial sebagai bagian dari pengalaman pelanggan. ${ }^{4}$

Saat ini telah beralih kepada era dimana transaksi tidak lagi dilakukan secara tatap muka, melainkan sudah melalui media on-line. Tidak lagi harus terjadi pertemuan antara penjual dengan pembeli di pasar, melainkan cukup dengan menggunakan teknologi internet dan langsung terjadi transaksi antara penjual dan pembeli. Telah terdapat berbagai macam produk yang dijual tidak lagi melakukan penjualan secara tatap muka semata, melainkan sudah

and the NSF Industry/University Cooperative Research Center (CISE/EEC) to the Center for Research on Information Technology and Organizations (CRITO) at the University of California, Irvine, hal 1364.

${ }^{3}$ Stephen Guo, Mengqiu Wang, and Jure Leskovec, "The Role of Social Networks in Online Shopping: Information Passing, Price of rust, and Consumer Choice", Research by NSF CNS, (juni 2011), hal 2.

${ }^{4}$ Stephen Guo, Mengqiu Wang, and Jure Leskovec, "The Role of Social Networks in Online Shopping: Information Passing, Price of rust, and Consumer Choice", Research by NSF CNS, (Juni 2011), hal. 2. 
menggunakan teknologi untuk melakukan penjualan secara on-line. ${ }^{5}$ Dengan teknologi canggih dan saluran internet yang terjamin, kepercayaan konsumen akan dapat meningkat. ${ }^{6}$

Menurut survey APJII, untuk mengikuti trend dunia belanja online mulai marak juga di Indonesia. Walaupun demikian kebanyakan dari pengguna online di Indonesia belum terlalu berani turut serta dalam belanja online. Menurut survey pengguna internet perempuan lebih berani melakukan belanja online (58\%) dibanding pengguna internet laki-laki (42\%).

Ada beberapa komoditas utama dalam kegiatan belanja online yang dilakukan oleh pengguna internet di Indonesia. Berikut grafik yang menggambarkan komoditas belanja online:

\section{Produk yang dibeli dari belanja online}

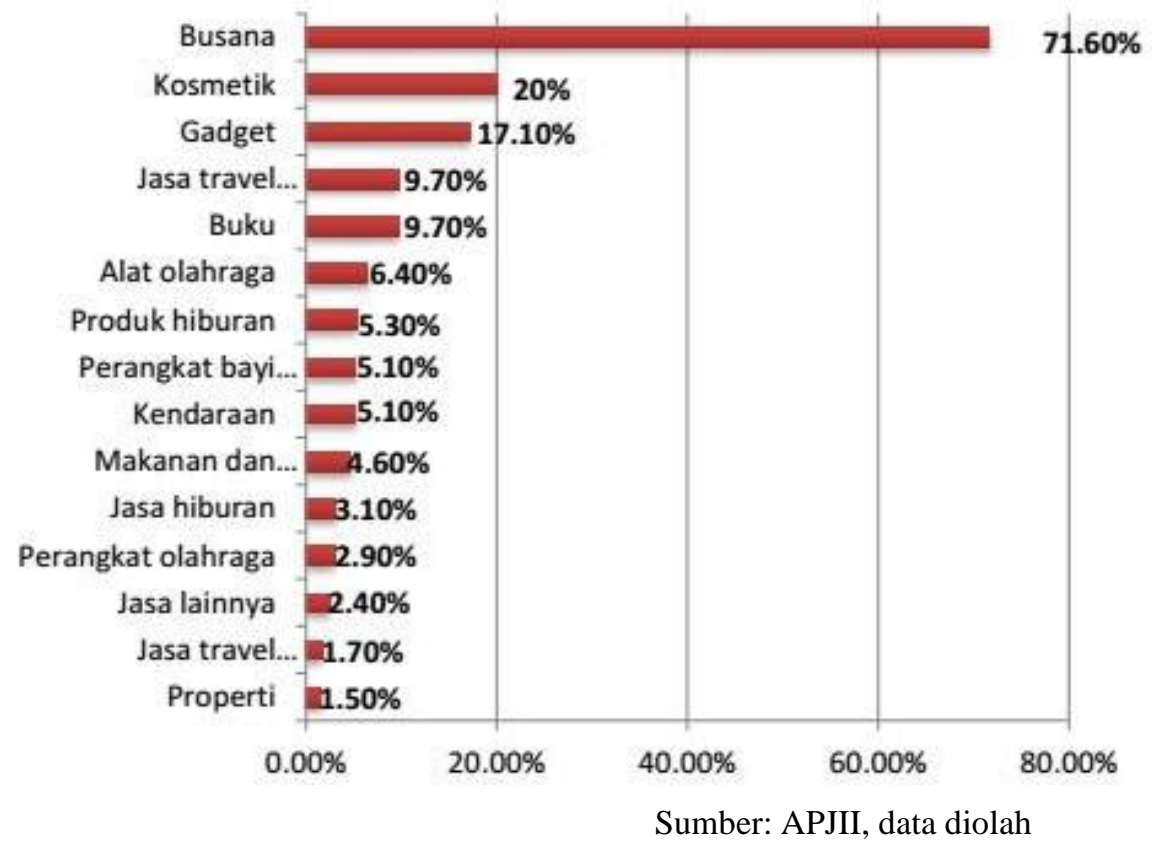

${ }^{5}$ Nur Rianto Al Arif, "Penjualan On-Line Berbasis Media Sosial dalam Perspektif Ekonomi Islam", Jurnal Ijtihad Stain Salatiga, Vol. 13, No. 1, (Juni: 2013), hal. 2.

${ }^{6}$ Gurvinder S Shergill and Zhaobin Chen, "Web-Based Shopping: Consumers' Attitudes Towards Online Shopping in New Zealand", Journal of Electronic Commerce Research, Vol. 6, No. 2, 2005 ,hal. 83 
Jika mengamati grafik ada lima komoditas utama dalam kegiatan belanja online yang dilakukan oleh para pengguna internet di Indonesia. Kelima komoditas tersebut adalah busana (dilakukan oleh $72 \%$ pengguna), kosmetik (dilakukan oleh 20 pengguna), gadget ataupun perangkat komunikasi (dilakukan oleh 17\% pengguna), jasa travel perjalanan (dilakukan oleh $9.7 \%$ pengguna) dan buku (dilakukan oleh $9.7 \%$ pengguna).

Ditengah perkembangan bisnis online yang kian menjamur ternyata tidak diiringi dengan bertambahnya kualitas maupun etika bisnis yang baik. Bisnis online yang terjadi di negara Indonesia sekarang ini masih menimbulkan banyak persoalan salah satunya yang dilakukan para pelaku bisnis online tersebut. Tak jarang pengguna online juga enggan untuk melakukan belanja secara online dikarenakan beberapa sebab. Berikut grafik yang mengambarkan penyebab orang tidak melakukan belanja online

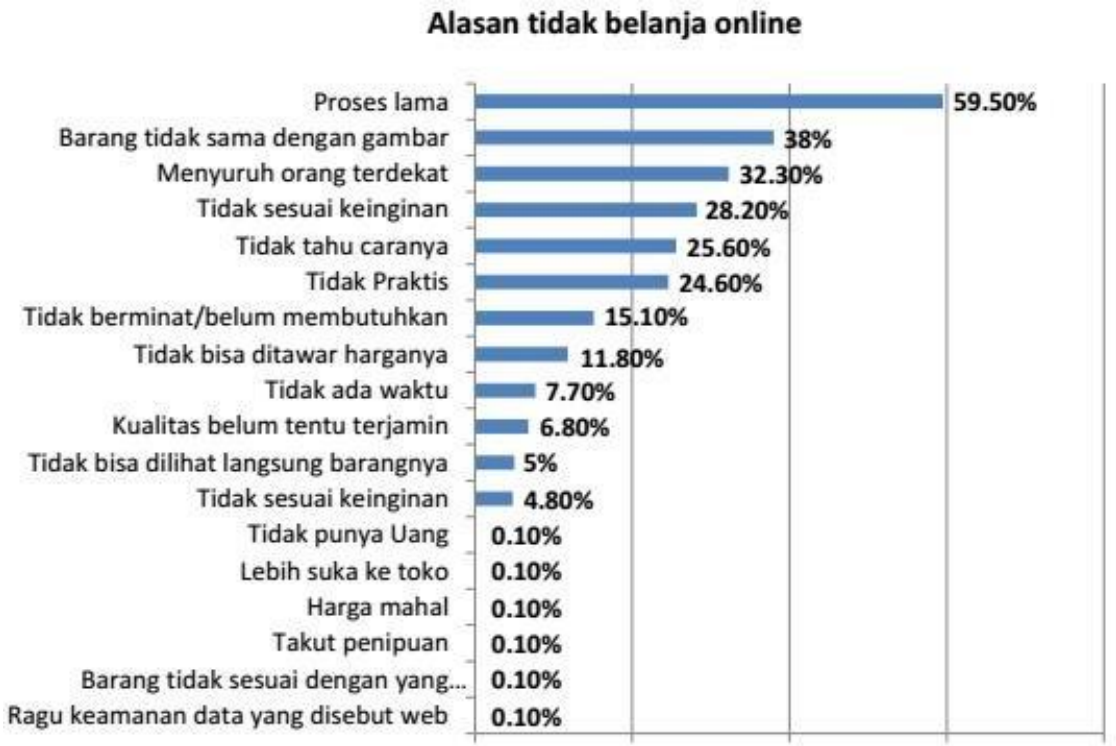

Sumber: APJII 
Sebanyak $72,7 \%$ pengguna internet menyatakan belum pernah melakukan belanja online. Faktor utama yang menyurutkan niat pengguna internet melakukan belanja online adalah karena mereka beranggapan akan memakan proses yang lama (59.5\%), dan alasan kedua terbanyak adalah barang yang dijual tidak sama dengan yang ada di gambar (38\%).

Selain pihak pembeli, bisnis online juga terdapat beberapa masalah bagi para penjual. Sebagian penjual enggan untuk menjual barangnya di media sosial maupun website. Grafik berikut merupakan hasil survey yang dilakukan APJII terkait beberapa alasan penyebab orang enggan melakukan penjualan online:

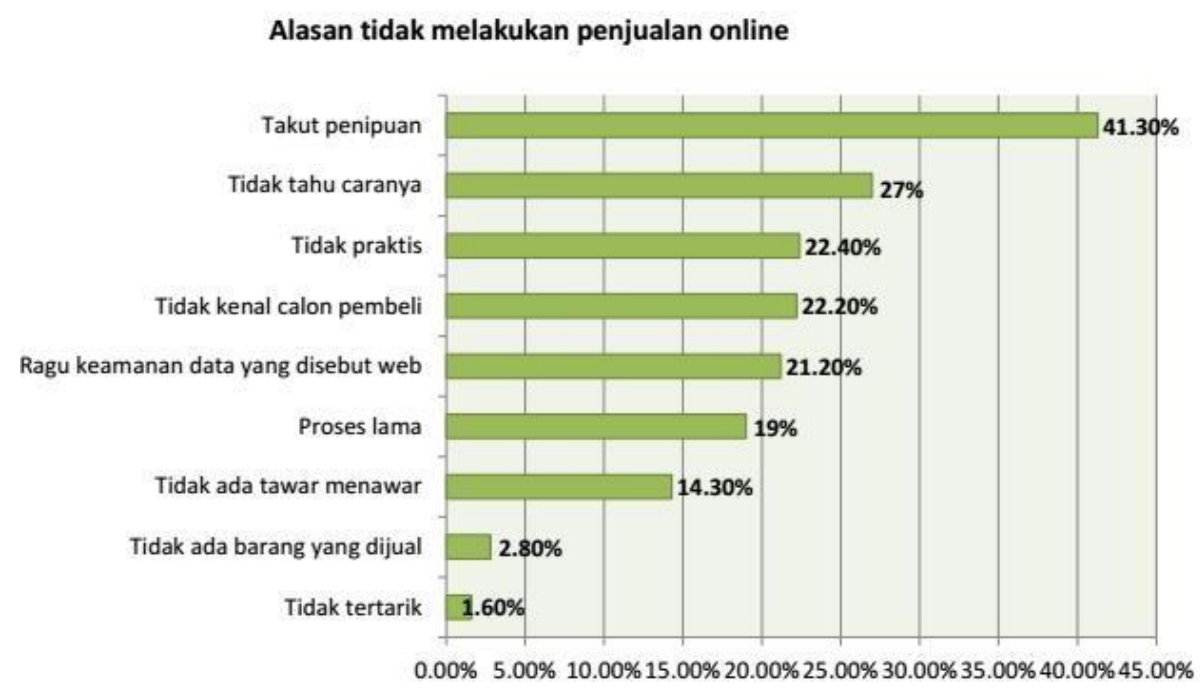

Sumber: APJII

Terlihat pada grafik penyebab orang tidak melakukan penjualan online yang terbanyak karena takut penipuan, hal ini cukup menjelaskan bahwa bisnis online masih rawan penipuan, ketidakpercayaan pada publik, serta peran pemerintah yang belum melindungi hak-hak produsen maupun konsumen. Padahal negara Indonesia merupakan penduduk terbesar yang beragama islam.

Alasan terbanyak yang kedua adalah tidak tahu caranya. Hal ini merupakan tantangan dalam melakukan e-commerce di negara-negara berkembang salah satunya 
Indonesia yang tingkat melek huruh dan teknologinya masih rendah. Negara-negara ini harus menempatkan upaya untuk memberikan perhatian lebih pada pendidikan penduduk. Ini karena kita tidak dapat melakukan bisnis melalui internet dengan konsumen yang tidak bisa membaca dan menulis. ${ }^{7}$

Banyak sekali situs-situs toko online dan telah berhasil mengintegrasi review produk, rekomendasi, mencari produk perbandingan. Tetapi, banyak situs lebih lambat dalam mengadopsi fitur jejaring sosial sebagai bagian dari pengalaman pelanggan. ${ }^{8}$ Desain website, kehandalan situs / pemenuhan, layanan pelanggan situs dan keamanan situs atau privasi adalah fitur yang paling menarik yang mempengaruhi persepsi konsumen membeli secara online. ${ }^{9}$ Kualitas situs yang lebih tinggi memiliki dampak penting terhadap pilihan konsumen terhadap toko online dan mengarah pada kepuasan konsumen. ${ }^{10}$ Karakteristik desain website serta melibatkan produk dan layanan yang memenuhi tingkat dimensi diferensiasi akan mempengaruhi perilaku konsumen toko online. ${ }^{11}$

Salah satu cara yang telah dieksplorasi adalah memberikan jaminan web layanan pihak ketiga untuk membantu menanamkan kepercayaan konsumen di pengecer online. Alternatif kedua, meningkatkan reputasi perusahaan atau toko online yang mampu mengurangi efek resiko yang dirasakan pada sikap dan perilaku belanja

\footnotetext{
${ }^{7}$ Ibid., hal 8 .

8 Stephen Guo, Mengqiu Wang, and Jure Leskovec, "The Role of Social Networks in Online Shopping: Information Passing, Price of rust, and Consumer Choice", Research by NSF CNS, (juni 2011), hal 2 .

${ }^{9}$ Gurvinder S Shergill and Zhaobin Chen, "Web-Based Shopping: Consumers' Attitudes Towards Online Shopping in New Zealand", Journal of Electronic Commerce Research, Vol. 6, No. 2, 2005 , hal. 83 .

10 Kamariah and Salwani (2000) in Gurvinder S Shergill and Zhaobin Chen, Web-Based Shopping: Consumers'...hal. 83.

${ }^{11}$ Ellisavet Keisidou, Lazaros Sarigiannidis, Dimitrios Maditinos, "Consumer Characteristics and their effect on aceepting online shopping, in the context of different product types", Journal of business and applied management, vol. 6, issue 2, (2011), hal. 44.
} 
konsumen. Ketika pengecer online memiliki reputasi yang baik, bahkan jika risiko tinggi, konsumen masih memiliki keyakinan dalam transaksi online. ${ }^{12}$

\section{E-Commerce dalam Perspektif Syariah}

\section{Prinsip perdagangan dalam Islam}

Allah dan Rasulnya telah menetapkan pertukaran barang dengan persetujuan antara kedua belah pihak dalam suatu transaksi dagang sebagai sesuatu yang halal atau dibolehkan, dan melarang mengambil benda orang lain tanpa persetujuan dan izin dari mereka. Selain itu untuk menjaga perdamaian dan ketertiban dalam masyarakat, hal ini juga sangat penting untuk memelihara hubungan yang baik dan harmonis dikalangan anggota masyarakat. Nabi Muhammad SAW telah meletakkan dasar-dasar hukum dan peraturan guna melakukan transaksi-transaksi dan juga telah memberikan hak untuk meneruskan atau membatalkan transaksi dengan syarat-syarat tertentu. ${ }^{13}$ Berkaitan dengan perdagangan, Allah SWT telah menegaskan dalam firmanNya:

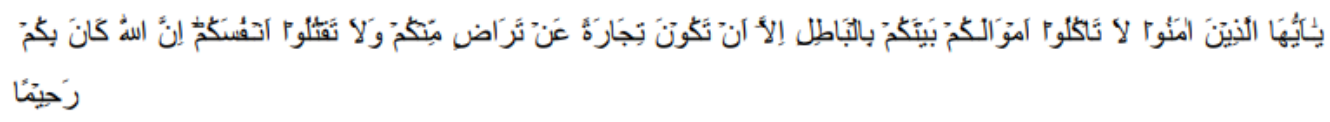

Hai orang-orang yang beriman, janganlah kamu saling memakan harta sesamamu dengan jalan yang batil, kecuali dengan jalan perniagaan yang berlaku dengan suka sama-suka di antara kamu. ${ }^{14}$

${ }^{12}$ Lina Zhou, Liwei Dai, and Dongsong Zhang, "Online Shopping Acceptance Model-A Critical Survey of Consumer Factors in Online Shopping", Jornal of Electronic Commerce Research, Vol. 8, No. 1,(2007), Hal. 57.

13 Afzalur Rahman, Muhammad: Encyclopedia of Seerah (Muhammad sebagai seorang Pedagang), alih bahasa Dewi Nurjulianti dkk dalam Haris Faulidi Asnawi, Transaksi Bisnis ECommerce Perspektif Islam, (Yogyakarta: Magistra Insania Pers, 2004), hal. 75.

${ }^{14}$ An-Nisa (4):29. 


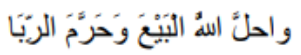

...Allah telah menghalalkan jual beli dan mengharamkan jual beli dan mengharamkan riba... ${ }^{15}$

Sementara Rasulullah SAW pernah ditanya oleh sahabat mengenai profesi yang paling baik. Rasulullah SAW menjawab:

Usaha manusia dengan tangannya sendiri dan setiap jual beli yang baik. $^{16}$

Kegiatan ekonomi merupakan salah satu dari aspek mu'âmalah dari sistem (ekonomi) Islam, sehingga kaedah fikih yang digunakan dalam mengidentifikasi transaksi ekonomi, termasuk dalam transaksi perniagaan elektronik juga menggunakan kaedah fikih mu' âmalah. ${ }^{17}$

\section{Hukum Bisnis Online}

Sebagaimana yang diketahui ada empat rukun akad, yaitu: (a) ada pihak-pihak yang berakad; (b) shighah atau ijab qabul; (c) Al-ma'qud alaih atau objek akad; (d) tujuan pokok akad tersebut dilakukan. Pihak-pihak yang berakad dalam penjualan on-line telah jelas, yaitu ada yang bertindak sebagai penjual dan ada yang bertindak sebagai pembeli. Shighah dalam penjualan online biasanya berupa syarat dan kondisi yang harus disetujui oleh konsumen. Syarat dan kondisi (term and conditions) yang harus disetujui dapat dipahami

${ }^{15}$ Al-Baqarah (2):275.

${ }^{16}$ HR. Al-Bazzar dari Rifaah ibn Rafi dan dibenarkan oleh al-Hakim; Lihat Muhammad Ibn Ismail ats-Tsan'ani, Subul as-Salam, Cet.4 (Beirut: Dar Ihya at-Turasy al-Arabi, 1379H), III:4.

17 Muhammad Sinhar, E-Commerce Dalam Perspektif Fikih Kontemporer, http://muhsinhar.staff.umy.ac.id/e-commerce-dalam-perspektif-fikih-kontemporer/. Diakses 10 Mei 2017. 
sebagai sebuah shighah yang harus dipahami baik oleh produsen maupun oleh konsumen. ${ }^{18}$

Dalam hal penjualan on-line bentuk shighah yang dilakukan adalah dengan cara tulisan. Contohnya apabila kita membeli suatu program melalui telepon pintar (smartphone) akan ada pilihan bahwa konsumen telah membaca dan menyetujui aturan dan perjanjian yang dibuat. Syarat dan kondisi yang disetujui ini merupakan shighah yang harus dipahami baik oleh produsen maupun konsumen pada penjualan on-line. Begitu pula apabila kita melakukan transaksi dengan menggunakan media sosial, penjual harus menulis syarat dan kondisi apa saja yang terdapat dalam transaksi tersebut, sehingga terjadi keterbukaan antara penjual dan pembeli.

Kemudian objek akad dalam transaksi, dalam penjualan on-line objek akad harus jelas dan barang harus secara sempurna dimiliki oleh si penjual. Tidak boleh dalam penjualan on-line maupun penjualan tatap muka, barang belum dikuasai secara sempurna oleh si penjual. Hal ini bertujuan untuk menjaga agar tidak terjadi penipuan oleh si penjual. Penjual dalam penjualan on-line harus secara jelas menulis berbagai spesifikasi dari barang yang dijual termasuk kekurangan dari barang tersebut jika ada.

Tujuan dari akad tersebut harus sesuai dengan syariat. Sehingga penjualan on-line tidak boleh menjual barang yang tidak sesuai dengan aturan syariat. Misalkan menjual bayi dalam penjualan on-line seperti yang terjadi pada salah satu situs jual beli beberapa waktu yang lalu; atau; situs penjualan senjata atau narkoba. Bentuk contoh transaksi tersebut tidak diperkenankan, karena bertentangan dengan aturan syariat. Terkait dengan rukun akad, penjualan on-line baik yang berbasis media sosial ataupun media lainnya diharamkan apabila memenuhi beberapa kriteria di bawah ini:

${ }^{18}$ Syaikh Shalih bin Fauzan bin Abdullah Al-Fauzan, Ringkasan Fikih Lengkap, (Jakarta: PT Darul Falah, 2008), hal. 488. 
a. Sistemnya haram, contohnya ialah perjudian on-line.

b. Barang ataupun jasa yang ditawarkan oleh pembeli ialah barang atau jasa yang diharamkan syariat Islam. Beberapa contoh barang atau jasa yang haram untuk diperjualbelikan adalah narkoba, senjata api, prostitusi, penjualan anak, dan berbagai objek transaksi haram lainnya.

c. Terdapat pelanggaran perjanjian atau terjadinya unsur penipuan. Hal ini banyak terjadi pada penjualan on-line berbasis media sosial, dimana barang yang ditawarkan di media sosial seringkali berbeda dengan barang yang diterima oleh konsumen. Apabila terindikasi unsur penipuan, maka bentuk jual beli tersebut status hukumnya adalah haram.

Mayoritas ulama Muslim sepakat bahwa selain kata, penawaran dan penerimaan terjadi dalam bentuk tulisan atau perilaku (dikenal sebagai $\left.m u^{\prime} a t a h\right)$, di mana tidak penjual atau pembeli mengungkapkan penawaran dan penerimaan atau hanya satu pihak mengatakan tawaran itu dan yang lainnya menerima melalui tindakan. Namun demikian, mereka tidak mengizinkan tawaran yang dalam bentuk pertanyaan, seperti "Anda akan membeli dari saya" atau "akan Anda menjual baik saya" karena ketidakpastian dari kalimat.

Jika perusahaan membuat kesepakatan dengan pelanggan untuk menghasilkan produk yang dipesan dan mengambil uang dari pelanggan hanya setelah produk dibuat, adalahperdagangan manufaktur Penjualan. Dan jika perusahaan setuju untuk menjual produk untuk pelanggan harga 
ditangguhkan atau di angsuran, maka itu adalah penjualan yang ditangguhkan. ${ }^{19}$

\section{Etika Bisnis Online}

Islam memiliki etika bisnis sendiri yang mengatur semua aspek bisnis serta kehidupan sehari-hari. Dalam kerangka etika Islam, perdagangan berlangsung melalui persetujuan bersama di pasar, dengan penekanan pada kepastian kontrak, dan langsung memfasilitasi keterbukaan dan menghilangkan ambiguitas. $^{20}$

Di dalam kegiatan bisnis, prinsip 'itikad baik (good faith)' dan 'Pacta sunt servanda ${ }^{21}$, menjadi prinsip yang utama dalam setiap transaksi perdagangan. Prinsip-prinsip ini menjadi prinsip utama dalam perdagangan internasional. Prinsip-prinsip ini menjadi semacam "kode etik (code of conduct)" untuk setiap orang yang akan melakukan bisnis dengan tidak merugikan orang lain.

Dalam konteks ini, pemahaman akan agama memainkan peran yang sangat penting dalam membentuk karakter manusia, sehingga kegiatan bisnis dapat dijalankan dengan jujur. Karena dalam konteks ini, manusia tidak hanya berurusan dengan sesama manusia saja, akan tetapi yang lebih penting dari itu, ia akan berhadapan dengan Allah, pemilik semua aturan di alam. Moralitas agama adalah kekuatan utama dalam membentuk etika manusia. Pengembangan etika bergantung kepada moralitas agama. Agama adalah pemberi inspirasi utama

19 Norazlina Zainul, Fauziah Osman, Siti Hartini Mazlan, "E-Commerce from an Islamic Perspective", Electronic Commerce Research and Aplications 3 (2004) 280-293.hal. 285.

20 Wilson, 2006 dalam Mohammed Naif Alotaibi and Mehmet Asutay, "Islamic Banking and Islamic E-Commerce: Principles and Realities", International Journal of Economic, Commerce and Management, Vol. III, Issue 4, April 2015.hal. 10

${ }^{21}$ Pacta sunt servanda adalah berasal dari bahasa "agreements must be kept". 
untuk membentuk "moral standard" dalam melakukan bisnis dengan etika yang baik. $^{22}$

Sesuai dengan agama Islam, transaksi bebas dari gharar dan penipuan. Selain itu, menyebutkan empat faktor yang membuat e-bisnis Islam yang sukses. Pertama, mengacu pada homolslamicus (man Islam) sebagai lawan homoeconomicus (ekonomi manusia) dalam memperluas e-bisnis Islam, menunjukkan bahwa menjadi individu termotivasi secara moral adalah inti dari bisnis syariah. Kedua, cara di mana lingkungan bisnis dapat mempengaruhi $e$ bisnis Islam, mengacu pada pentingnya pemangku kepentingan yang besar di masyarakat. Ketiga, berkaitan dengan penerapan aturan dan peraturan, sebagai ebisnis Islam harus dipraktekkan secara ketat untuk memastikan sukses, tetapi yang paling penting Syariah compliant, transaksi. Keempat, berkaitan dengan peran pemerintah, dalam bahwa pemerintah harus mendorong orang-orang untuk menggunakan peluang e-bisnis karena keamanan dan, di atas semua karena tanpa kesalahan menurut Islam. ${ }^{23}$

\section{Solusi E-Commerce Perspektif Syariah dalam Membangun ekonomi Digital}

Dari berbagai pemaparan yang cukup jelas diatas mengenai bisnis online, ternyata masih cukup banyak tantangan ataupun persoalan yang dihadapi untuk mewujudkan e-commerce yang islami. Untuk menjawab tantangan dan persoalan tersebut, penulis berusaha untuk menawarkan solusi agar bisnis online lebih baik lagi melalui skema berikut:

22 Imas Rosidawati dan Edy Santoso, "Pelanggaran Internet Marketing pada Kegiatan ECommerce Dikaitkan dengan Etika Bisnis”, Penelitian kerjasama Universitas Islam Nusantara dengan BPSDM Kementrian Hukum dan HAM, (Januari-Juni 2012), hal. 13-14.

${ }^{23}$ Amin 2008 in Mohammed Naif Alotaibi and Mehmet Asutay, "Islamic Banking and Islamic ECommerce: Principles and Realities", International Journal of Economic, Commerce and Management, Vol. III, Issue 4, April 2015.hal. 11. 


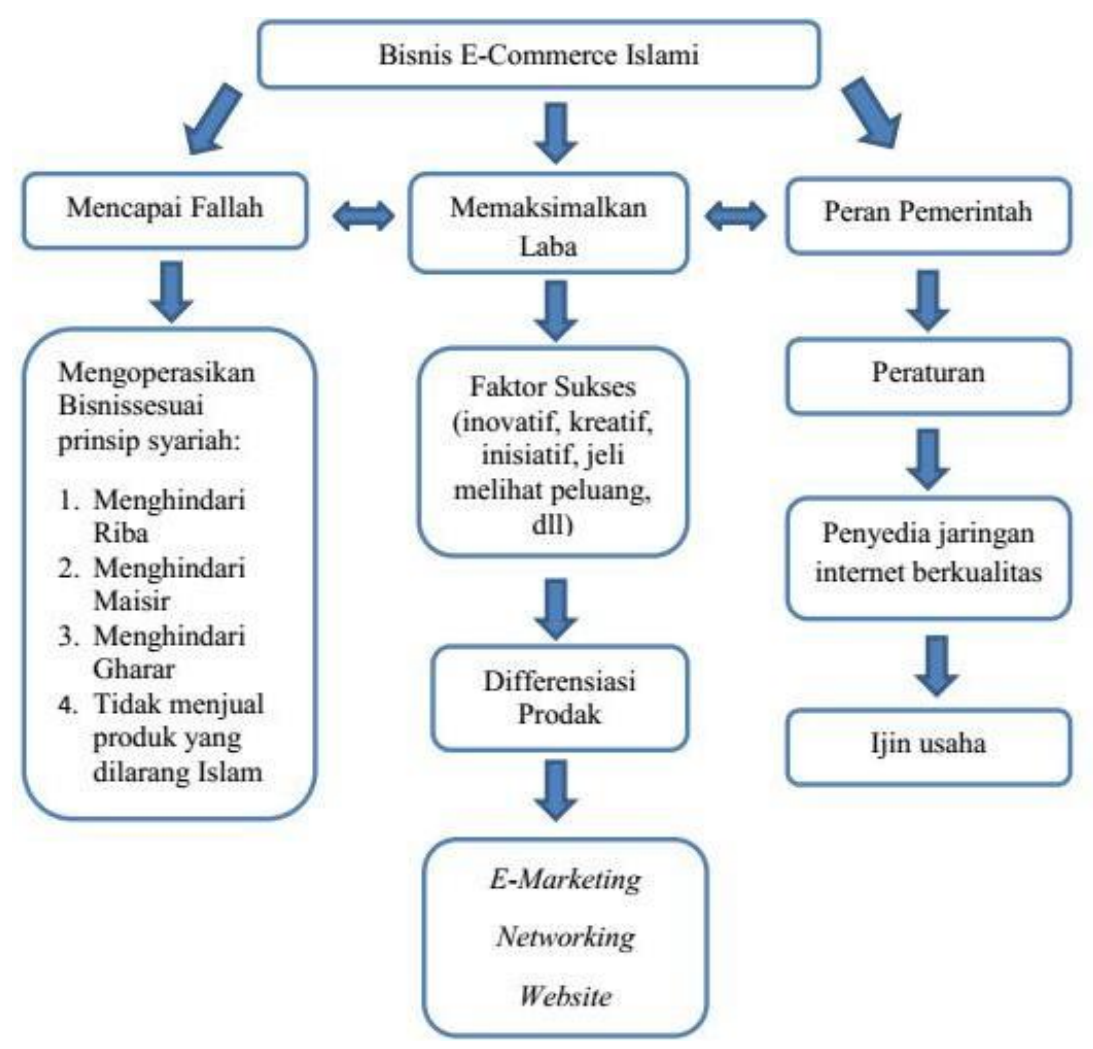

\section{Mencapai Falah}

Untuk melakukan bisnis online perspektif salah satunya harus menghindari riba. Tantangan bagi bisnis online Islam dalam usahanya menghindari riba dan akan memilih pembayaran dan sistem perbankan yang sesuai syariah. Hal ini penting karena operasional dasar bisnis online adalah sistem pembayaran perbankan. Dalam sistem kita saat ini, sebagian besar perdagangan domestik dan internasional menggunakan sistem keuangan konvensional yang dikonotasikan dan terkait dengan riba. ${ }^{24}$

Tantangan berikutnya adalah untuk menghindari unsur-unsur gharar dalam membeli dan menjual kontrak. Untuk menghindari gharar, pihak

\footnotetext{
${ }^{24}$ Ibid ., hal. 6.
} 
kontraktor harus (i) memastikan bahwa kedua subjek dan harga penjualan ada, dan mampu untuk disampaikan; (ii) menentukan karakteristik dan jumlah dari nilai counter; (iii) menentukan kuantitas, kualitas dan tanggal pengiriman masa depan, jika ada. Jika dua larangan, Riba dan Gharar, dapat dihindari bersama dengan dua lainnya larangan, bisnis Islam bisa mencapai salah satu dari dua gol, yang merupakan maksimalisasi Falah.

Penggunaan kartu kredit untuk membeli barang secara online dan kemudian membayar harga pembelian oleh angsuran ke bank atau penerbit kartu pada kenyataannya merupakan bentuk pinjaman ke kartu-pembawa. Jadi, penerbit tidak berhak menerima lebih dari jumlah yang diambil untuk membeli. Namun, penerbit diperbolehkan untuk mengambil biaya tetap dengan nama biaya administrasi, dan biaya tersebut tidak increasable karena peningkatan uang yang digunakan untuk pembelian. Yang pasti, memaksakan persentase pada jumlah uang yang digunakan oleh kartu kredit adalah Riba (riba dan bunga) dalam dirinya sendiri, apakah persentase tersebut diambil sebagai biaya pelayanan dan biaya administrasi atau karena keterlambatan penyelesaian. Kedua bentuk adalah pinjaman riba dan bentuk yang paling terkenal dari Riba dari sistem non-Islam. ${ }^{25}$

Oleh karena itu, dalam transaksi E-Commerce, yang Murabahah Sistem dapat digunakan sebagai alternatif Metode pembayaran menggantikan kartu kredit. Selain itu, terdapat berbagai cara untuk secara online pembayaran seperti pembayaran melalui cek elektronik, dan kartu debit. ${ }^{26}$

Penyimpangan etika dalam saluran distribusi seperti yang yang menyebabkan penundaan yang tidak perlu dalam pengiriman mereka, pelanggan kuat untuk kembali berulang kali dan dengan demikian menyebabkan mereka

25 Ainnur Hafizah Anuar Mokhtar, Tamrin Amboala, Mohd Zulkifli Muhammad, and Mohd Sarwar, "E-Alam, Bai As-Salam and E-Commerce: A Comparative Analysis from Shariah Perspective", Proceeding of the 2nd Applied International Business Conference, (7-8 December 2013). hal. 527.

${ }^{26}$ Norazlina Zainul, Fauziah Osman, Siti Hartini Mazlan, "E-Commerce from an Islamic Perspective...,hal. 286. 
ketidaknyamanan yang tidak perlu. Sebagai Islam bisnis beroperasi sesuai dengan prinsip syariah, maka akan phase out ketidakpastian di mencapai pelanggan. Bisnis akan lebih tergantung pada pemasaran langsung, keterlibatan kurang dari agen dan akan memanfaatkan Internet untuk mencapai pelanggan belanja online. $^{27}$

\section{Memaksimalkan Laba}

Faktor kenyamanan merupakan salah satu hal yang dinilai mudah untuk browsing atau mencari informasi melalui online lebih mudah daripada belanja secara tradisional. Melalui online, konsumen dapat dengan mudah mencari katalog produk. Tetapi, misal jika konsumen melihat hanya untuk untk satu produk di toko secara tradisional untuk melihat secara fisik barangnya akan terasa sulit dan memakan waktu. ${ }^{28}$ Konsumen lebih peduli tentang atribut situs web terkait dengan resiko yang dirasakan, misal: keamanan informasi an keandalan perusahaan daripada terkait dengan kenyaman yang dirasakan yang mendasari pentingnya mengurangi ketidakpastian belanja online dan resiko.

Kriteria yang sama harus diterapkan jika kita ingin mengubah bauran pemasaran tradisional untuk campuran e-marketing terutama ketika kita harus mematuhi prinsip-prinsip dan pedoman Syariah. Pendekatan terbaik atau strategi yang harus digunakan untuk memasarkan Islam e-commerce adalah dengan menggunakan bauran pemasaran konsep (4P).

Dengan menjual melalui Internet, perusahaan dapat memenuhi pelanggan mereka informasi, kebutuhan transaksional dan layanan di cepat dan biaya yang efisien. Dalam berpegang pada prinsip-prinsip Islam, bisnis Islam harus memiliki produk, informasi lengkap atau deskripsi tentang produk, dan harus memiliki

${ }^{27}$ Gurvinder s shergill, "Web based shopping..., hal. 94.

${ }^{28}$ You Qinghe, Chen Wenyuan, and Liu Kaiming, "The Online Shopping Change the Retail Business Model: A Survey of The People Use Online Shopping in China", IOSR Journal of Business and Management e-ISSN: 2278-487, p-ISSN: 2319-7668. Volume. 15, Issue 5, (Jan 2014), hal. 83. 
kemampuan untuk memberikan produk. Selanjutnya investasi di kegiatan usaha yang dianggap dilarang dalam Islam bukan sesuatu seorang Muslim harus melakukan.

Karena ukuran pasar, Internet akan memiliki efek paling besar pada tempat dalam bauran pemasaran. E-commerce menempatkan keputusan pembelian di mana saja yang koneksi ke Internet ada. Jangkauan global Internet akan menciptakan pasar yang lebih besar dan pertumbuhan yang kuat dari utilitas jaringan. eksploitasi teknologi elektronik baru akan menawarkan baru, lebih berorientasi pelanggan, pendekatan kewirausahaan untuk saluran pemasaran.

\section{Peran Pemerintah}

Cita-cita pemerintah yang ingin menempatkan Indonesia sebagai Negara Ekonomi Digital terbesar di Asia Tenggara pada 2020 tentunya sistem perekonomian digital yang telah ada mulai harus diperbaiki, tentunya mengimbau kepada pemerintah untuk mempersiapkan industri ini. Tidak ada yang salah dengan fokus pemerintah untuk mengembangkan industri padat karya. Sebab, mayoritas sumber daya manusia Indonesia sekarang adalah lulusan SD-SMP dan SMA-SMK. pemerintah tetap harus mempersiapkan industri berbasis teknologi informasi yang salah satu turunan bisnisnya adalah ekonomi digital. Ini penting sebab peluang bisnisnya besar dan akan menjadi tren ke depan.

Pemerintah mulai sekarang harus mempersiapkan peraturan yang mengatur tentang bisnis online baik untuk prodisen dan konsumen, sehingga berbagai tindak kriminal yang merugikan dapat diurus secara hukum. Peraturan pemerintah selama ini memang menjadi acuan dalam setiap tindakan yang dilakukan di Indonesia.

Pemerintah harus menyiapkan dua hal sejak sekarang. Pertama adalah menciptakan sumber daya manusia berkualitas. Harus semakin banyak lulusan minimal S-1 yang berkualitas. Kedua adalah membangun infrastruktur teknologi 
informasi, seperti mengembangkan infrastruktur untuk $4 \mathrm{G}$ dan meluaskan jaringan ke seluruh pelosok Nusantara.

Untuk menghadapi MEA yang isunya akan dibuka mulai akhir Desember 2015 pemerintah harus memfasilitasi para pengusaha khususnya UKM dalam hal perijinan usaha. Meskipun sekarang pemerintah telah memfasilitasi surat IUKM ( Ijin Usaha Kecil Mikro) di setiap Kabupaten. Namun, masih sedikit saja kabupaten yang sudah dapat diakses. Masih banyak kabupaten di Indonesia yang belum dapat mengakses surat ini dikarenakan belum siap peraturan daerahnya.

\section{KESIMPULAN}

Transaksi online dibolehkan menurut Islam berdasarkan prinsip-prinsip yang ada dalam perdagangan menurut Islam, khususnya dianalogikan dengan prinsip transaksi as-salam, kecuali pada barang/jasa yang tidak boleh untuk diperdagangkan sesuai syariat Islam. Bisnis online sama seperti bisnis offline seperti biasanya. Ada yang halal ada yang haram, ada yang legal ada yang ilegal. Hukum dasar bisnis online sama seperti akad jual beli dan akad as-salam, ini diperbolehkan dalam Islam.

Dalam prakteknya di Indonesia yang mayoritas penduduknya beragama Islam, namun ternyata masih banyak penyimpangan-penyimpangan terjadi yang tidak sesuai dengan prinsip syariah. Hal ini mungkin terjadi karena ketidak tahuan masyarakat kita terhadap menjalankan bisnis yang sesuai prinsip syariah dan tentu saja menimbulkan ketidaktahuan ini kerugian bagi orang lain.

Terdapat beberapa aspek yang bisa dijadikan solusi untuk menghindari penyimpangan-penyimpangan yang terjadi seperti apa yang telah dijelaskan sebelumnya, mulai dari peran pelaku bisnis online sampai peran pemerintah yang cukup mendukung. Apabila semuanya ini telah dilakukan, pasar ekonomi digital perspektif syariah akan tercapai. Sudah saatnya bagi negara Indonesia membangun pasar, bukan seperti selama ini yang menjadi target pasar. 


\section{DAFTAR PUSTAKA}

Syaikh Shalih bin Fauzan bin Abdullah Al- Fauzan, Ringkasan Fiqih Lengkap, (Jakarta: PT.Darul Falah), 2008.

Faulidi Haris, Asnawi, Transaksi Bisnis E-Commerce Perspektif Islam, (Yogyakarta: Magistra Insania Pers), 2004.

Abdulrahman Alzaagy, "The Islamic Concept of Meeting Place and its Application in E-Commerce", Masaryk University Journal of Law and Technology. Vol. 1, No. 1. ISSN 1802-5943. (2008).

Ainnur Hafizah Anuar Mokhtar, Tamrin Amboala, Mohd Zulkifli Muhammad, and Mohd Sarwar E-Alam, "Bai As-Salam and E-Commerce: A Comparative Analysis from Shariah Perspective", Proceeding of the $2^{\text {nd }}$ Applied International Business Conference 7-8 (December 2013).

Ellisavet Keisidou, Lazaros Sarigiannidis, Dimitrios Maditinos, "Consumer Characteristics and their effect on aceepting online shopping, in the context of different product types", Journal of business and applied management, vol. 6, issue 2, (2011).

Gurvinder S Shergill and Zhaobin Chen, "Web-Based Shopping: Consumers' Attitudes Towards Online Shopping in New Zealand", Journal of Electronic Commerce Research, Vol. 6, No. 2, 2005.

Hanudin Amin, "E-Business from Islamic Perspectives: Prospects and Challeges", Journal of Internet Banking and Commerce, Vol. 13, No. 3, (december 2008).

Hatem El-Gohary, "E-Marketing - A literature Review from a Small Businesses Perspective", International Journal of Business and Social Science, Vol. 1 No. 1, (October:2010).

Hotlan Siagiandan Edwin Cahyono, "Analisis Website Quality, Trust dan Loyalty Pelanggan Online Shop", Jurnal Manajemen Pemasaran, Vol. 8, No. 2, (Oktober 2014).

Imad ad Dean Ahmad, "Islam, Commerce, and Business Ethics", Plenary address at the Loyola Institute for Ethics and Spirituality in Business International Ecumenical Conference (June 10-12, 2004).

Imas Rosidawati dan Edy Santoso, "Pelanggaran Internet Marketing pada Kegiatan ECommerce Dikaitkan dengan Etika Bisnis", Penelitian kerjasama Universitas 
Islam Nusantara dengan BPSDM Kementrian Hukum dan HAM, (Januari-Juni 2012).

Liang Chen \& Clyde W. Holsapple, "E-Business Adaption Research: State of The Art”, Journal of Electronic Commerce Research, Vol. 14 No. 03, (2013).

Lina Zhou, Liwei Dai, and Dongsong Zhang, "Online Shopping Acceptance Model-A Critical Survey of Consumer Factors in Online Shopping", Jornal of Electronic Commerce Research, Vol. 8, No. 1, (2007).

Marjan Muhammad and Kulliyyah of Information and Communication Technology, "Towards Shari'ah Compliant E-Commerce Transactions: A Review of Amazon.com", Middle-East Journal of Scientific Research 15 (9): 1229-1236, 2013 ISSN 1990-9233.

Mary Wolfinbarger and Mary Gilly,"Consumer motivation for Online Shopping”, This research has been supported by grants from the CISE/IIS/CSS Division of the U.S. National Science Foundation and the NSF Industry/University Cooperative Research Center (CISE/EEC) to the Center for Research on Information Technology and Organizations (CRITO) at the University of California, Irvine.

Mohammed Naif Alotaibi and Mehmet Asutay, "Islamic Banking and Islamic ECommerce: Principles and Realities", International Journal of Economic, Commerce and Management, Vol. III, Issue 4, (April 2015).

Mohammed Nalf Alotaibi and Mahmet Asutay, "Islamic Bankin and Islamic ECommerce: Principles and Realities", International Journal of Economic, Commerce and Management, Vol. III, Issue 4, (April 2015).

Mohd Zulkifli Muhammad, Tamrin Amboala, and Mohd Fahmi Ghazali, "Comprehensive Approach for Sharia' Compliance E-Commerce Transaction", Journal of Internet Banking and Commerce, April 2011, Vol. 16, No. 1.

Muhd Rosydi Muhammad and Marjan Muhammad, "Building Trust in E-Commerce: A Proposed Shari'ah Compliant Model", Journal of Internet Banking and Commerce, Vol. 18, No. 3, (december 2013).

$\mathrm{Na}$ Li and Ping Zhang, Eighth Americas Conference on Information System 2000, "Consumer Online Shoppimh Attitudes and Behavior: An Assessment of Research".

Norazlina Zainul, Fauziah Osman, Siti Hartini Mazlan, "E-Commerce from an Islamic Perspective", Electronic Commerce Research and Aplications 3 (2004). 
Nur Rianto Al Arif, "Penjualan on-line Berbasis Media Sosial dalam Perspektif Ekonomi Islam", Jurnal Ijtihad Wacana Hukum Islam dan Kemanusiaan, Vol. 13 No. 1, (Juni:2013).

Nuradli Ridzwan Shah Bin Mohd Dali and friends, "Islamic Businesses and ECommerce Challenges and Opportunities", Presented by Faizah Mohd Khalid at UNITEN SCORE Conference, (3 December 2003).

Nuradli Ridzwan Shah bin Mohd Dali, Mohd Zainal Munshid bin Harun, Faizah Bte Mohd Khalid, Hanifah Bte Abdul Hamid, "E-Commerce in Islamic Perspectives. The Theoretical Framework, Key Success Factor and Challenges for Islamic E-Commerce Business", Proceeding of Knowledge Management International Conference (13 th to $15^{\text {th }}$ February 2004).

Oviliani Yenty Yuliana, "Penggunaan Teknologi Internet dalam Bisnis", Jurnal Akuntansi \& Keuangan Fakultas Ekonomi Universitas Kristen Petra, Vol. 2, No. 1, (Mei 2000).

Seda Yoldas, "A Research About Buying Behaviours of Online Customers Comparison of Turkey with UK", A Dissertation Submitted for The Masters in MSc International Management, The Business School University of Roehampton, (2011).

Selvia Nuriasari, "Bisnis Online dalam Perspektif Islam", Jurnal Hukum dan Ekonomi Syariah, Vol. 02 No. 1.

Shofiyullah, dkk, "E-Commerce dalam Hukum Islam (Studi atas pandangan Muhammadiyah dan NU)", Jurnal Penelitian Agama, Vol XVII, No. 3 (September-Desember: 2008).

Stephen Guo, Mengqiu Wang, and Jure Leskovec, "The Role of Social Networks in Online Shopping: Information Passing, Price of rust, and Consumer Choice", Research by NSF CNS, (juni 2011).

Taesu Cheong, Mark Goh, and Sang Hwa Song, "Effect of Inventory Information Discrepancy in a Drop-Shipping Supply Chain", Journal of The Decision Sciences Institute, Vol. 46, No. 1, (Februari 2015).

Tamrin Amboala, Ainnur Hafizah Anuar Mokhtar,etc, "Development Method for Shariah Compliant e-Commerce Payment Processing", International Journal of Computer Theory and engineering, Vol. 7, No. 5, (October 2015). 
LABATILA: Jurnal 1 lmu Ekonomi lslam e-ISSN: $2621-3818$ Vol: 1, No. 2, Juni 2018

You Qinghe, Chen Wenyuan, and Liu Kaiming, "The Online Shopping Change the Retail Business Model: A Survey of The People Use Online Shopping in China", IOSR Journal of Business and Management e-ISSN: 2278-487, p-ISSN: 2319-7668. Volume. 15, Issue 5, (Jan 2014). 